\title{
EFFECT OF MINERAL OIL ON REINFORCED CONCRETE STRUCTURES PART I. DETERIORATION OF COMPRESSIVE STRENGTH
}

\section{Hesham Diab}

Civil Eng. Dept., Faculty of Eng., Assiut University, Assiut 71516, Egypt

(Received September 12, 2011 Accepted October 29, 2011)

\begin{abstract}
This paper is the first part of general study started at Assiut University dealing with effects of mineral oil on reinforced concrete structures. This study focused on the impact of used engine oil on the compressive strength of concrete. Compressive strength of concrete cubes soaked in used mineral oil for six months were compared with that of oil-free concrete cubes. Five different concrete mixes were adopted to investigate the aggressiveness of mineral oil on low and high strength concrete. Furthermore, this paper describes an investigation into the effect of oil saturation on concrete frame foundations used for large machines of Cement Assiut factory-CEMEX. It is concluded that evaluation of the aggressive effect of mineral oil on concrete by comparing the strength on oil-free concrete and oiled concrete at the same age experimentally is the optimal and most reliable of the existing method. The aggressiveness of oil is very clear for low and high strength concrete and the reduction in compressive strength is 17, and 11.8 percent respectively. Additionally, based on the field study, degree of oil saturation in concrete plays an important role in compressive strength.
\end{abstract}

KEYWORDS: Oil; used mineral oil; low and high strength concrete; compressive strength

\section{INTRODUCTION}

Concrete is a mixture of cement, water, fine aggregate and coarse aggregate, which hardens to a stone-like mass. Concrete is used more than any man made materials on earth. The concrete strength is often regarded as the most important property of concrete. Concrete suffers from one major draw back compared with other materials like steel and timber; its strength can not be measured prior to it being placed. Factors affecting compressive strength are water cement ratio, mix ratio, degree of compaction, type of cement, the grade of aggregate, design constituent, mixing method, placement, curing method and presence of contaminates.

Reinforced Concrete (RC) elements in case of underground structures, garage buildings, and industrial constructions are subjected to Contamination of different materials, i.e. water, chemical and oil-product. Oil products affect tank walls, foundations and other constructions supporting machines, and storage floors, therefore, the range of the problem is wide and the subject should be considered of great technical importance, especially when regarding industrial construction. Oil leakage from machines above foundation has been considered the prime factor in the deterioration of $\mathrm{RC}$ elements supporting machines [1,2]. Comparing the influence of 
various oil products on compressive strength of concrete, leads to the conclusion that there are large differences in their effects [3-4].

The leakage of oil into the cement in older structures has been reported to result in concrete with greater resistance to freezing and thawing [6]. Accordingly, adding used engine oil to the fresh concrete mix could be similar to adding an airentraining chemical admixture, thus enhancing some durability properties of concrete while serving as a technique of disposing the oil waste. Hamad et al. [7] studied the effect of adding used engine oil, as an air-entraining agent, to concrete on the properties of the fresh and hardened concrete. The main conclusion of this study is that the used engine oil improves the fluidity of concrete mix and reduces the properties of hardened concrete. Moreover, the 28- and 90-day concrete compressive strength of the used engine dependent on the water cement ratio.

Generally, raw materials for concrete production should be free from oil contamination. However, Ayininuola [8] studied the impact of contaminated sand in order of 2, 5 and $10 \%$ of both diesel oil and cut-bitumen separately, on the compressive strength of concrete. It was concluded that, on comparing with controlled concrete cubes, presence of diesel oil and bitumen of any proportion in sand result in concrete of lesser compressive strengths. This study revealed clearly that diesel oil and bitumen are compressive strength inhibitors in concrete production. Additionally, Ajagbe [9] studied the effect of aggregate contaminated with crude oil and concluded that aggregate containing more than $5 \%$ crude oil contamination reduces compressive strength of concrete more than $50 \%$.

In recent years, deterioration has been found in the concrete structures subjected to oil and this deterioration depended on the quality of the concrete and its density (impermeability) [3,10,11]. The oiling of structural elements is a problem presented in industrial building. Strongly oiled concrete floors display considerable damage, which often impairs a building's exploitation. After a few years, significant enlargement of cracks brought about by the influence of oil can be observed [2]. Błaszczyński [10] and Biczok [12] presented an example of an oiled, reinforced, concrete floor in which significant cracking and deflection occurred and, during repair work, concrete was easily separated from reinforcement bars. The author also noticed, in frame foundations of industrial building (Assiut cement company-Cemex), a considerable damage which result in reduction of the structure's dynamic stiffness due to oil. The behaviour of oiled frame foundations is later analyzed in this study.

Pukhov [11] concluded that the mineral oil is aggressive with respect to concrete and the compressive strength of the oil-impregnated concrete was 20-63\% lower than that of oil-free concrete. On the other hand, some authors presented contradictory results regarding oiled concrete. The effects of oil products on concrete are classified either as non-harmful or only mildly harmful [3,13,14]. Gerbiec [13] presented contradictory results regarding oiled concrete, in his research, and concluded that the relatively long-term oiling samples (about 5.5 years) did not cause a decrease in compression and tensile strength below the initial values. Similar results were obtained by Ejeh [3]. Nevertheless; there is evidence that serious damage can be caused $[5,10,15]$. 


\section{RESEARCH SIGNIFICANCE}

Current research aims at investigating the impact of oiled concrete soaked in used oil for six months experimentally, in addition to field study carried out on three frame foundations have different degree of oil saturation at Cemex. Evaluation of the aggressiveness of oil is considered based on the performance of oiled concrete and that of oil-free concrete at the same age. Many factors were taken into consideration in this study such as permeability, water/cement ratio, admixtures, and strength of concrete.

\section{MATERIALS AND METHOD}

\subsection{Materials}

The material used to develop the concrete mixes in this study were Ordinary Portland cement, fine aggregate (F.A; sand), coarse aggregate (C.A; gravel), water, superplasticizer, and an air-entraining agent. Natural sand was used as a fine aggregate, and natural gravel of maximum size $40 \mathrm{~mm}$ was used as a coarse aggregate for normal strength concrete mix, while basalt gravel of maximum size $20 \mathrm{~mm}$ was used as a coarse aggregate for high strength concrete mix. Concrete were soaked in industrial mineral oil, Geer oil ISO VG 220, of kinematic viscosity in temperature $40^{\circ} \mathrm{C}(217.4$ $\mathrm{mm}^{2} / \mathrm{s}$ ). The used oil was obtained from machines of Assiut cement factory- CEMEXEgypt.

\subsection{Preparation of test specimens}

A total of four main mixes were prepared in five groups to illustrate performance of concrete soaked in oil for six months. The target 28-day compressive strength in $\mathrm{MPa}$ of these mixes was 17.5, 25, 70 and 25 with an air-entraining agent. A superplasticizer complying with ASTM C-494 Type A, F was used for high strength concrete and an air-entraining agent was used to produce impermeable concrete mix. Details of the concrete types and their mix proportions are shown in Table 1.

\section{Table 1: concrete mix types and their mixtures}

\begin{tabular}{|l|c|c|c|c|c|c|c|c|}
\hline $\begin{array}{l}\text { Conc. } \\
\text { type }\end{array}$ & w/C & $\begin{array}{l}\text { Cement } \\
\left(\mathbf{k G} / \mathbf{M}^{\mathbf{3}}\right)\end{array}$ & $\begin{array}{l}\mathbf{F . A} \\
\left(\mathbf{k G} / \mathbf{m}^{\mathbf{3}}\right)\end{array}$ & $\begin{array}{l}\mathbf{C . A} \\
\left(\mathbf{k G} / \mathbf{m}^{\mathbf{3}}\right)\end{array}$ & $\begin{array}{l}\text { silica } \\
\left(\mathbf{k G} / \mathbf{m}^{\mathbf{3}}\right)\end{array}$ & $\begin{array}{l}\text { air- } \\
\text { entraining } \\
\text { agent }(\mathbf{k g})\end{array}$ & $\begin{array}{l}\text { Superp- } \\
\text { lasticizer } \\
(\mathbf{k G})\end{array}$ & $\begin{array}{l}\text { Slump } \\
(\mathbf{m m})\end{array}$ \\
\hline $\mathrm{C} 17.5$ & 0.74 & 250 & 678 & 1160 & --- & -- & -- & 105 \\
\hline $\begin{array}{c}\mathrm{C} 25, \\
\text { C25-B }\end{array}$ & 0.5 & 370 & 642 & 1100 & --- & --- & -- & 75 \\
\hline C25-A & 0.496 & 370 & 644 & 1100 & --- & 1.48 & -- & 75 \\
\hline C70 & 0.297 & 475 & 631 & 1168 & 47.5 & --- & 15.67 & sloppy \\
\hline
\end{tabular}

The mixture was mixed together in a small rotary mixer to produce a homogenous fresh concrete. Steel moulds of size $150 \times 150 \times 150 \mathrm{~mm}^{3}$ with inside coated oil were placed on flat steel plate. Fresh concrete was poured into the waiting moulds in three equal layers. Using a tamping rod, each layer was tamped 25 times to remove entrapped air afterward, the top surface of concrete was trowel smooth and leveled with the top of mould. After 24 hours, the cubes were removed from moulds and completely immersed in water for 28 days. 
Experimental program consists of 42 cubes divided into five groups. Group I, $\mathrm{C} 17.5$, has an expected 28-day compressive strength equal to $17.5 \mathrm{MPa}$ and represents low strength and high porous concrete. Group II, C25, has an expected 28-day compressive strength equal to $25 \mathrm{MPa}$ which is most commonly used for industrial RC structures in Egypt. Group III, C25-A, has an air-entraining agent to reduce permeability of concrete. Group IV, C25-B, represents concrete which is protected by surface coating. Three layers of bitumen were painted to the surface of cubes before immersing in oil tank. Group V, C70, represents high strength and low porosity concrete.

\subsection{Experimental procedures}

The procedure adopted to study the compressive strength of oiled concrete is as follows:-

1) After curing period, altogether 30 concrete cubes were heated to about $100^{\circ} \mathrm{C}$ and were weighted. About two months later, at age 100 days, 15 cubes were immersed in a tank filled with the used gear oil, except Group IV, C25-B, which was coated by three layers of bitumen and, after drying, it also, immersed in the same oil tank for six months. The other 15 cubes were kept in laboratory environment.

3) Concrete compressive strengths were determined experimentally on the 28 and 280 day of concrete cubes production. On 28 day, twelve cubes were crushed to determine the 28-compressive strength of cubes. Only three specimens represent $\mathrm{C} 25$ and $\mathrm{C} 25-\mathrm{B}$, as they have the same mix and no bitumen was added to the cubes until that day.

3) Two days before test, cubes were taken out from oil tank and scanned with dry cloth to remove oil from surfaces and then were weighted. On 280 day, thirty cubes were crushed made up of fifteen oiled-free cubes and fifteen oiled concrete which were soaked in oil for six months as shown in Fig. 1. Each cube was placed perpendicular to the cast face in contact with the platform of the testing machine. Load was applied in an increment $5 \mathrm{kN}$ per second until failure. Longitudinal deformations of cubes until failure were measured using dial gauge placed on moveable head of the machine as shown in Fig.1.

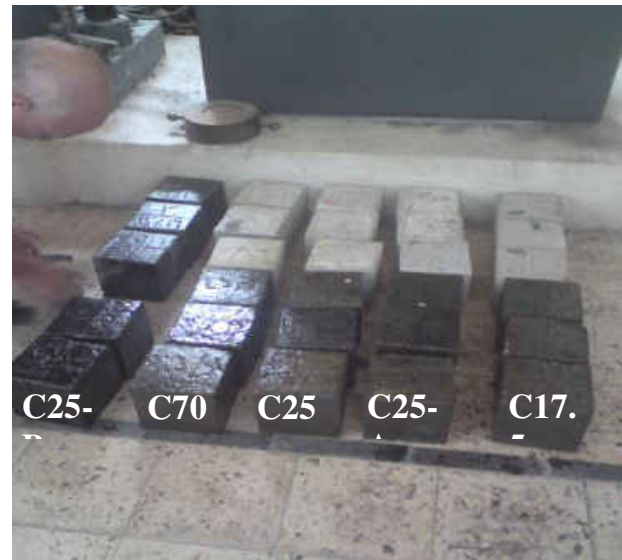

(a)

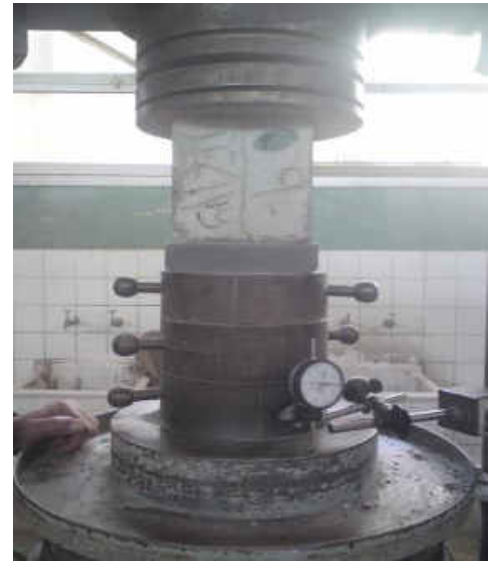

(b)

Fig. 1. (a) Specimens before and after exposed to mineral oil and (b) test set-up 


\section{EXPERIMENTAL RESULTS}

\subsection{Compressive strength}

The summary of the results of cube compressive strengths is shown in Table 2. It could be seen from this table that strength of oiled concrete at 280 days is a little higher than that obtained at 28 days. The average of strength percentage ratios based on 28-day strength is equal to 1.05 which means that oil has no aggressive effect on compressive strength of oiled concrete soaked in oil for six months. This finding is consistent with what was cited in the literature [11,15]. A higher increase percent is noticed for C25-B as shown in table 2. The possible reason for this higher increase may be due to change of test end conditions as cubes crushed at 28 days have no bitumen on surface which is contrary to cubes crashed at 280 days. Presence of bitumen may lead to increase bond and friction between cubes and head of machine. On the other hand, the minimum reduction of strength, based on 280-oil-free concrete compressive strength, noticed for C25-B which has the same end condition. Therefore, it can be concluded that coating concrete surface with bitumen is a reasonable method to protect concrete from oil effect.

Table 2: concrete types and test results of oiled and oil-free concrete cubes

\begin{tabular}{|c|c|c|c|c|c|c|c|}
\hline $\begin{array}{l}\text { Conc. } \\
\text { type }\end{array}$ & $\begin{array}{l}\text { Cube } \\
\text { No. }\end{array}$ & $\begin{array}{l}\mathbf{F}_{28} \\
(\mathbf{M P a})^{*}\end{array}$ & $\begin{array}{l}\mathbf{F}_{280-\mathbf{f}} \\
(\mathbf{M P a})^{* *}\end{array}$ & $\begin{array}{l}\mathbf{F}_{280-0} \\
(\mathbf{M P a})^{* * * *}\end{array}$ & $\begin{array}{l}\left(\mathbf{F}_{280-}\right. \\
\left.{ }_{0} / \mathbf{f}_{28}\right) \%\end{array}$ & $\begin{array}{c}\left(\mathbf{F}_{280-}\right. \\
\left.{ }_{0} / \mathbf{f}_{280-\mathrm{f}}\right) \%\end{array}$ & $\begin{array}{l}\text { Average } \\
\left(\mathbf{F}_{280-\mathrm{o}} / \mathbf{f}_{\mathbf{2 8 0 - \mathrm { f }}}\right) \%\end{array}$ \\
\hline \multirow{3}{*}{ C17.5 } & C17.5-1 & 15.00 & 19.52 & 16.24 & 102.8 & 88.07 & \multirow{3}{*}{83.0} \\
\hline & C17.5-2 & 16.91 & 15.89 & 12.37 & 78.3 & 67.07 & \\
\hline & C17.5-3 & 15.44 & 19.92 & 17.34 & 109.8 & 94.02 & \\
\hline \multirow{3}{*}{$\mathrm{C} 25$} & C25-1 & 28.36 & 34.06 & 30.72 & 108.2 & 93.45 & \multirow{3}{*}{90.7} \\
\hline & C25-2 & 28.80 & 32.70 & 32.11 & 113.1 & 97.70 & \\
\hline & C25-3 & 28.00 & 31.86 & 26.67 & 93.9 & 81.13 & \\
\hline \multirow{3}{*}{ C25-B } & C25-B-1 & 28.36 & 36.57 & 31.63 & 111.4 & 87.17 & \multirow{3}{*}{93.3} \\
\hline & C25-B-2 & 28.80 & 37.26 & 33.60 & 118.4 & 92.62 & \\
\hline & C25-B-3 & 28.00 & 35.00 & 36.47 & 128.4 & 100.51 & \\
\hline \multirow{3}{*}{ C25-A } & C25-A-1 & 34.00 & 40.15 & 40.06 & 119.6 & 101.30 & \multirow{3}{*}{88.5} \\
\hline & C25-A-2 & 32.60 & 38.45 & 34.61 & 103.3 & 87.51 & \\
\hline & C25-A-3 & 33.90 & 40.05 & 30.46 & 90.9 & 77.01 & \\
\hline \multirow{3}{*}{$\mathrm{C} 70$} & C70-1 & 64.98 & 74.96 & 77.33 & 115.4 & 99.68 & \multirow{3}{*}{88.1} \\
\hline & C70-2 & 71.53 & 81.33 & 67.11 & 100.2 & 86.51 & \\
\hline & C70-3 & 64.50 & 76.44 & 60.80 & 90.7 & 78.37 & \\
\hline \multicolumn{5}{|l|}{ average } & 105.6 & 88.81 & \\
\hline
\end{tabular}

${ }^{*} \mathrm{f}_{28}$-28-day compressive strength of oil free concrete

${ }^{* *} \mathrm{f}_{280-\mathrm{f}^{-}}$280-day compressive strength of oil free concrete

${ }^{* * * *} \mathrm{f}_{280-\mathrm{o}}$-280-day compressive strength of oiled concrete 
Results also show that the oil-free compressive strength of cubes tested at same age has a significant increase. A sound concrete is expected to have its compressive strength increased with ages, if it cured at normal condition. Percentage of variation of oiled concrete strength based on oil-free concrete strength at same age is listed in Table 2. It could be noticed that strength of oil-free concrete is higher than that of oiled concrete at same age. The variation of compressive strength is mainly due to oil effect i.e. oil has aggressive effect on compressive strength of concrete.

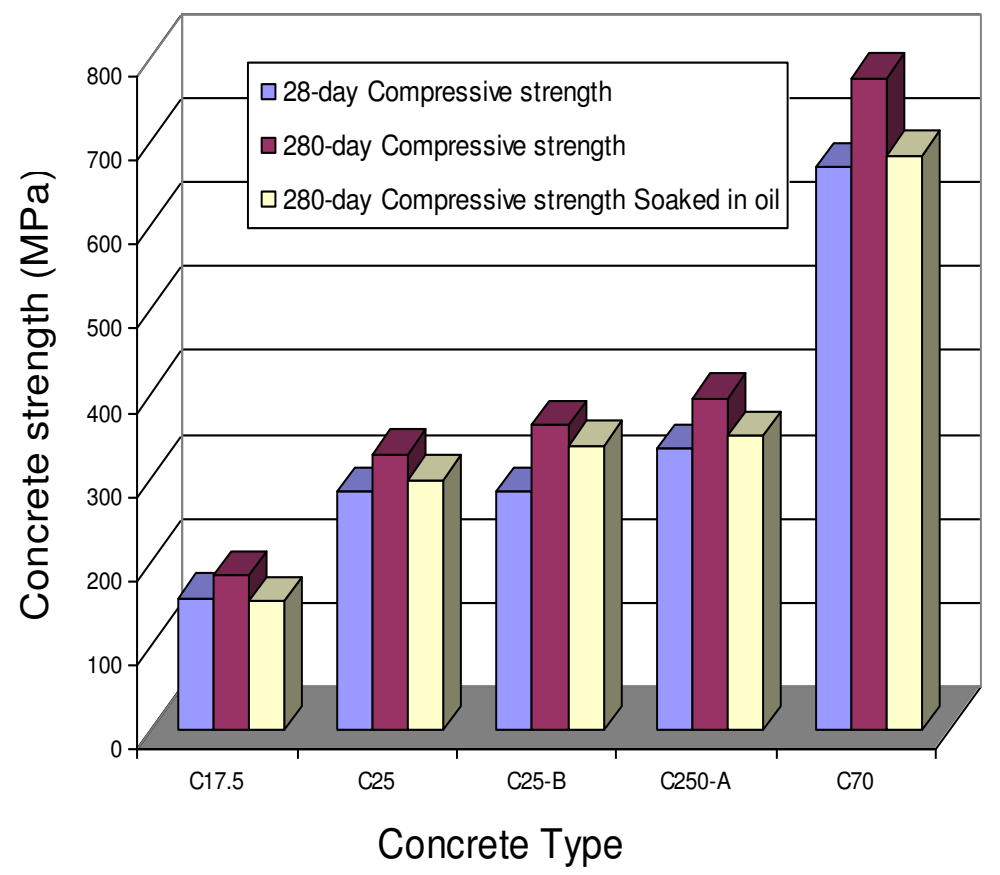

Fig. 2. Oiled and oiled free compressive strength

Averaging the entire test results obtained on both oil-free and oiled concrete compressive strength listed in Table 2 are shown also in Fig. 2. Moreover, Fig. 3 shows the percentage of variation of oiled concrete compressive strength based on both 28day and 280-day oil-free compressive strength. These figures give a clear explanation for the controversy about the oil effect. Based on the short period of this study, mineral oil results in a small reduction on compressive strength of low strength and high porosity concrete, $\mathrm{C} 17.5$, based on the 28-day compressive strength. However, the aggressiveness of oil is very clear when oiled concrete strength compared by that of oil-free at the same age. The variation of reduction of strength were 17\%, 9.2\%, 6.6\%, $11.9 \%$, and $11.4 \%$ for $\mathrm{C} 17.5, \mathrm{C} 25, \mathrm{C} 25-\mathrm{B}, \mathrm{C} 25-\mathrm{A}$, and $\mathrm{C} 70$, respectively. Effectiveness of bitumen is clear as $\mathrm{C} 25-\mathrm{B}$ has a minimum reduction percentage of strength. 


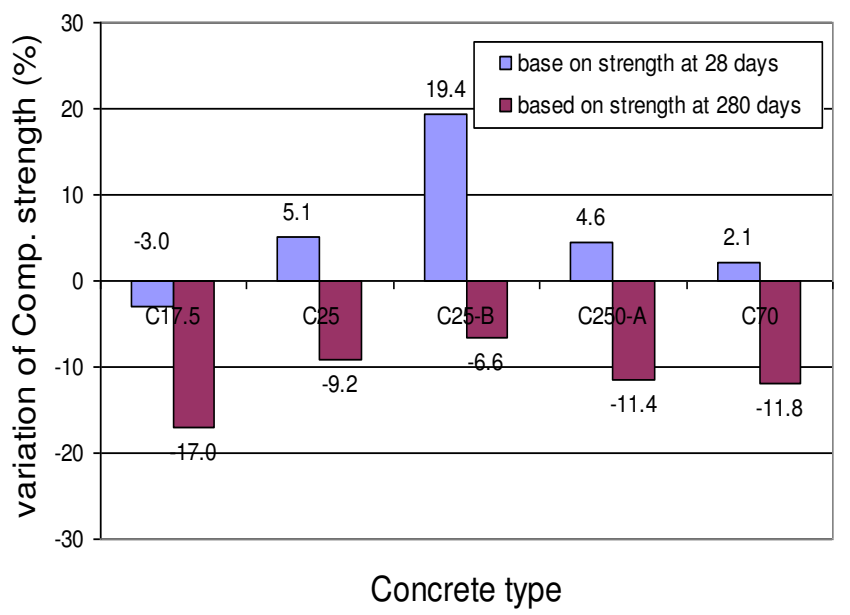

Fig. 3. Percentage of oiled concrete compressive strength based on that of oil free concrete

It is clear that presence of oil medium prevents strength gain. The little increase of oiled concrete strength based on the 28-day strength cubes is due to the strength gain occurred for concrete before immersing cubes in oil tanks. High reduction of strength percentage occurred for low strength concrete, C17.5, based on 28-day proves that oil has an aggressive effect on compressive strength for high porosity concrete.

The average oil absorption percentage by weight for C17.5, C25, C25-B, C25$\mathrm{A}$, and $\mathrm{C} 70$, was $2.19 \%, 0.4 \%, 0.2 \%, 0.3 \%$, and $0.25 \%$ (oven-dry basis) respectively. As is to be expected, the oil absorption is higher for concrete C17.5 than other types of concrete. Fig. 4 shows the penetration of oil through different types of concrete after crushing. By visual inspection, it is obvious that C17.5 is fully oil saturated whereas oil is penetrated only few millimeters from surface for C25-B and C70. on the other hand, the oil penetration is in the range of $10.0 \mathrm{~mm}$ to $20.0 \mathrm{~mm}$ from surface of $\mathrm{C} 25$ and C25-A as shown in Fig. 4. Bitumen as a protection material prevents oil diffusion into concrete, while air-entraining agent reduces the penetration of oil to concrete.

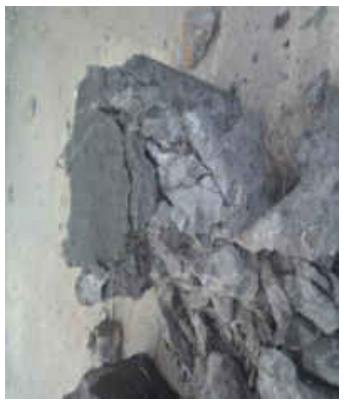

$\mathrm{C} 70$

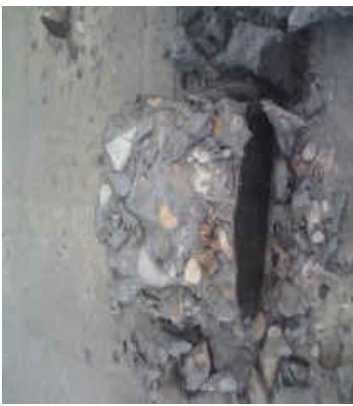

$\mathrm{C} 25-\mathrm{B}$

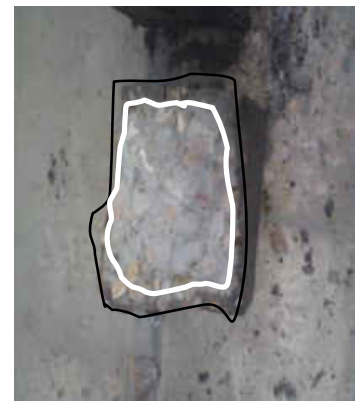

$\mathrm{C} 25$

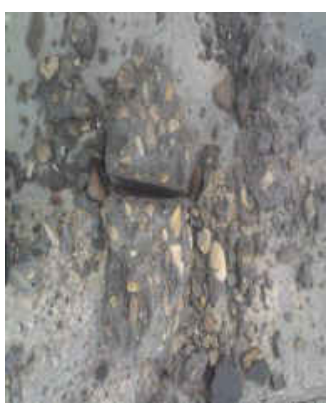

C17.5

Fig. 4. Oil penetration through different types of concrete 
Except C17.5, these very small differences in the average oil absorption values seem to indicate that oil diffusion has no effect on the strength and that any differences observed for oil-free concrete are probably due to cutting cement grains inside concrete off from moisture, arresting their further hydration.

\subsection{Load-displacement relationship}

Deformation of concrete cubes was monitored using dial gauge shown previously in Fig. 1. Therefore, beyond the maximum load, it was difficult to record displacement. Load-displacement curves of oil-free and oiled C17.5 are shown in Fig. 5. The stiffness of oil-free specimens nearly is similar and doesn't affect by the ultimate load as shown in Fig. 5(a). On the other hand, the presence of oil results in diversion of stiffness as shown in Fig. 5 (b). the value of stiffness is related to the ultimate load. The higher the ultimate load, the higher the stiffness. Comparison of load-displacement relationship of C17.5 of oiled and oil-free concrete is very interesting. While the load-displacement relationships for oil-free concrete specimens are quite similar, the load displacement relationships of oiled concrete specimens differ significantly. Thus, the aggressiveness of oil not only reduces compressive strength of concrete it also increases its compressibility and consecutively its modulus of elasticity. This performance of concrete is very clear for $\mathrm{C} 17.5$ where maximum reduction of strength occurred.

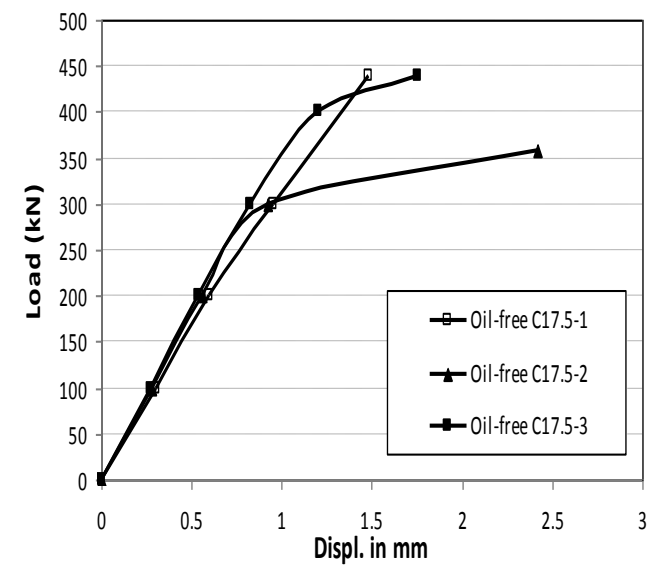

a) oil-free concrete

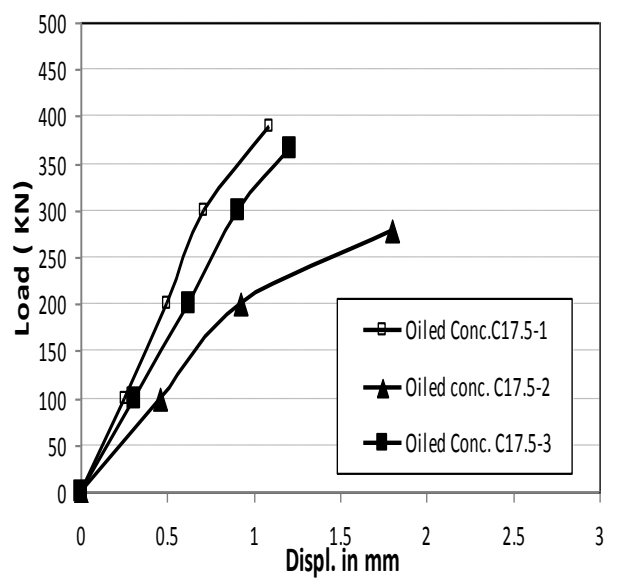

b) oiled concrete for 6 months

Fig. 5. Load-displacement relationship for C17.5 at age 280 days

\section{A CASE STUDY: EFFECT OF MINERAL OIL ON THE REINFORCED CONCRETE FRAME FOUNDATIONS OF ASSIUT CEMENT COMPANY- CEMEX}

In recent years, deterioration has been found in the concrete foundations of the first production line; cement Assiut Company- Cemex-Egypt. Machines are fixed by anchor bolts embedded into concrete with end thick steel plate as shown in Fig. 6. Oil dripped onto the foundations from loose flange of motors or gear boxes and during random spillages, oil impregnate concrete foundation and some places were saturated with gear oil (ISO VG 220) as shown in Fig. 6. Inspection team, of Cemex, noticed that 
vibrations of these machines were increasing with the passing of time as well as the nut of anchor bolts need to be fastening from time to time.

A special investigation was conducted by the Author to determine the effect of mineral oil on the concrete frame foundations of the first production line of Cemex. It was also noted, that strong oiling of the foundations is one of the main factors causing a decrease of the structure's dynamic stiffness of large power turbines $[5,10]$. The extent of the aggressive effect of the oil on the concrete was evaluated by comparing the strength of concrete cores drilled-out from reinforced concrete foundations. Three places were chosen to study concrete performance, base of raw material crusher (base I) and two bases of cement mill 5 (Base II, III). The first line production of Cemex was placed in service since about 30 years, and there is no available data concerning strength, mix or contents of concrete.

\subsection{Drilling core samples}

A total of ten holes were drilled in the three frame foundations with drill rig equipped with diamond bits $100 \mathrm{~mm}$ in diameter. Four holes were drilled in base I and six holes were drilled in Base II and III. In drilling the holes, it is endeavored to choose different degree of oil saturation of core specimens. The core then was soaked in water, capped with high strength concrete to make its ends plane, parallel, at right angle and then tested in compression in a moist condition [16]. Length of all cores is nearly $150 \mathrm{~mm}$ before capping and was $190 \mathrm{~mm}$ after capping i.e. height/diameter (H/D) ratio equals two for all cores. The cores were visually inspected to determine degree of oil saturation and measure depth of oil as shown in Fig.7. That figure shows core specimens before and after capping. Degree of saturation was determined by measuring length of core containing oil and divided on the whole length of core before capping.
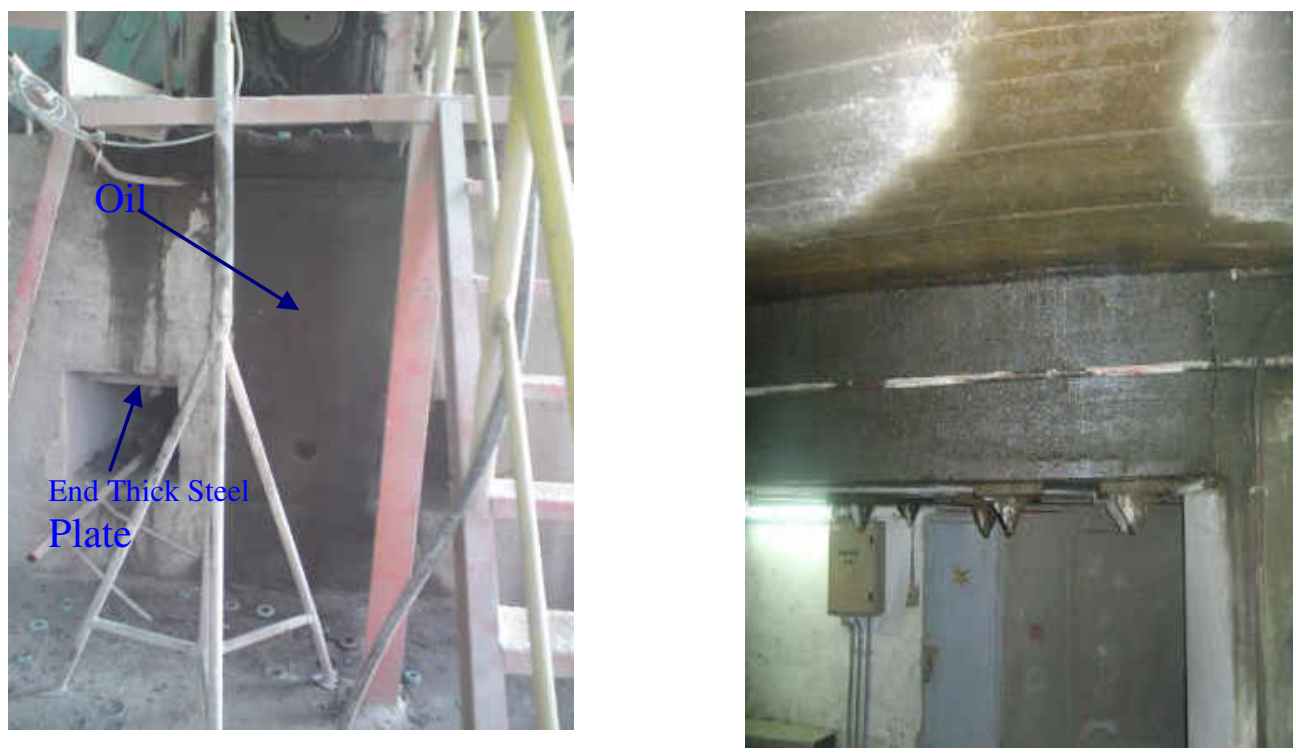

Fig. 6. Foundation of crusher contaminated by mineral oil 


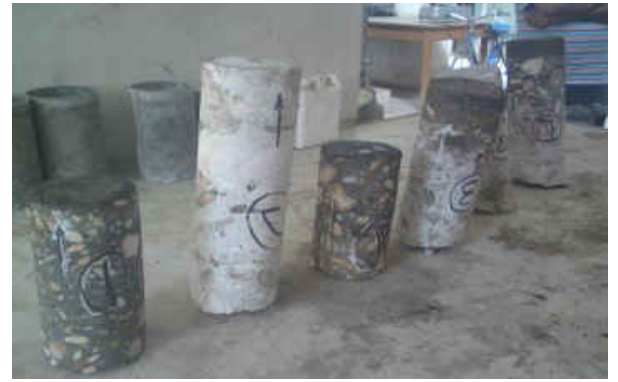

a) Before capping

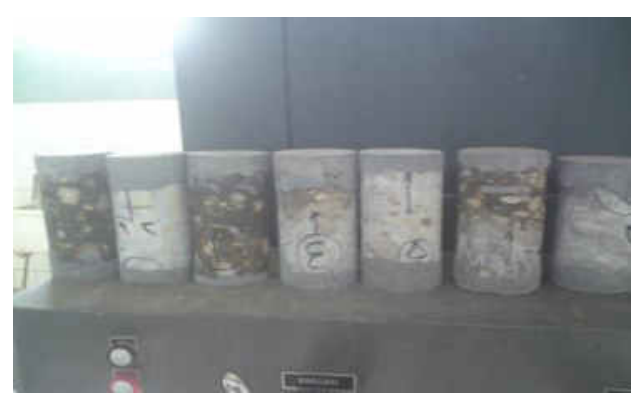

b) after Capping

Fig. 7. Samples of concrete cores before and after capping

Table 3: test results of concrete cores removed from CEMEX Frame

foundations.

\begin{tabular}{|c|c|c|c|c|c|c|}
\hline $\begin{array}{l}\text { Place of } \\
\text { foundation }\end{array}$ & $\begin{array}{c}\text { Core } \\
\text { number }\end{array}$ & $\begin{array}{c}\text { Percentage of } \\
\text { oil } \\
\text { contamination }\end{array}$ & $\underset{\text { ty }}{\operatorname{densi}}$ & $\begin{array}{l}\text { Compressive } \\
\text { strength- f } \\
\text { (MPa) }\end{array}$ & $\begin{array}{c}\text { Average } \\
\text { compressive } \\
\text { strength- } \\
\mathbf{f}_{\mathrm{m}}(\mathbf{M P a})\end{array}$ & $\begin{array}{c}\text { Strength } \\
\text { Ratios } \\
\left(\mathbf{f} / \mathbf{f}_{\mathbf{m}}\right)\end{array}$ \\
\hline \multirow{4}{*}{$\begin{array}{l}\text { Crusher base } \\
\text { (base I) }\end{array}$} & I-1 & 67 & 2.3 & 8.0 & \multirow[t]{4}{*}{8.5} & 0.94 \\
\hline & I-2 & 90 & 2.41 & 7.9 & & 0.93 \\
\hline & I-3 & 100 & 2.31 & 7.6 & & 0.89 \\
\hline & I-4 & 27 & 2.34 & 10.5 & & 1.24 \\
\hline \multirow{3}{*}{$\begin{array}{l}\text { Cement mil } \\
\text { (base II) }\end{array}$} & II-1 & 100 & 2.23 & 16.1 & \multirow[t]{3}{*}{14.4} & 1.12 \\
\hline & II-2 & 0.0 & 2.24 & 14.1 & & 0.98 \\
\hline & II-3 & 100 & 2.32 & 13.0 & & 0.90 \\
\hline \multirow{3}{*}{$\begin{array}{l}\text { Cement mill- } \\
\text { gear box base } \\
\text { (base III) }\end{array}$} & III-1 & 0.0 & 2.28 & 20.1 & \multirow[t]{3}{*}{18.1} & 1.11 \\
\hline & III-2 & 53 & 2.31 & 18.5 & & 1.02 \\
\hline & III-3 & 87 & 2.35 & 15.9 & & 0.88 \\
\hline
\end{tabular}

\subsection{Results}

Testing of the cores was carried out according to Egyptian code of practices [16] and ASTM C42-99 [17]. Table 3 lists compressive strengths of concrete cores, density of concrete, and degree of oil contamination. The average compressive strength of the three bases has a big Discrepancy and they are less than the design strength which is expected to not less than $25 \mathrm{MPa}$. The degree of oil contamination has a significant influence on the strength of concrete, as the compressive strength decreases with the increase of oil contamination except specimen II-1 which has no explanation. Moreover, Fig. 8 confirms the aggressive effect of oil as the strength ratio decreases with the increase of the oil contamination.

Based on the average compressive strength of each base, the reduction of strength is related to the soaked period of oil, which is represented by the degree of oil contamination. The longer oil soaked period, the higher the degree of oil contamination in cores. The variation of density of cores is not only due to oil absorption but also due to the presence of steel bars in some specimens. These observed variations in strength of cores were similar to that obtained from experimental results in C17.5. 


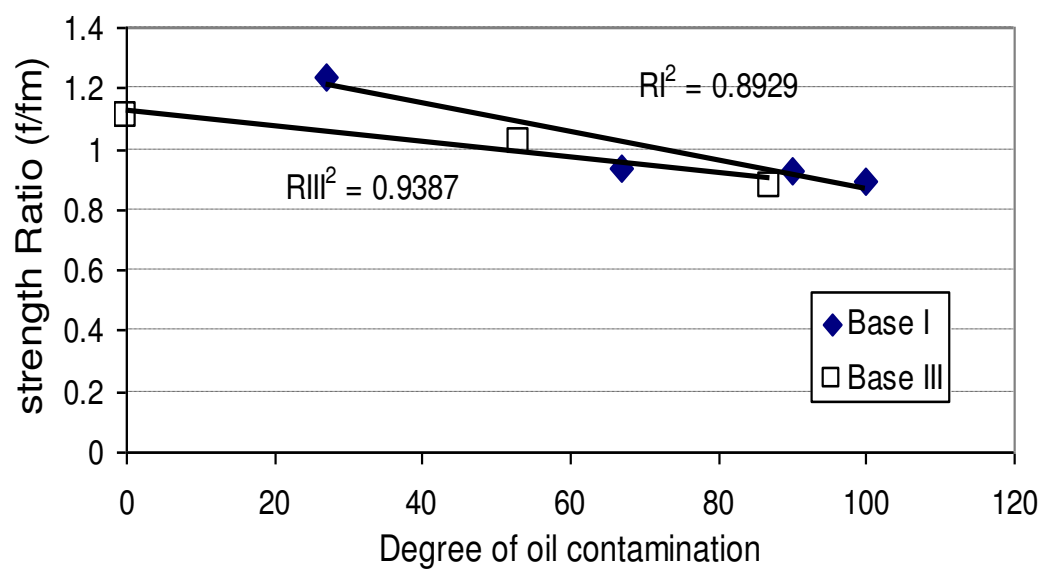

Fig. 8. Compressive strength ratio of oiled concrete cores removed from the R.C frames of CEMEX bases

Experimental and field study shows that oil has an aggressive effect on the concrete strength. The extent of this aggressiveness depends on the quality of the concrete and its density (impermeability). An oil medium is most aggressive for porous low-density concrete such as C17.5 and field concrete cores, where oil penetrates into smallest pores as shown previously in Fig. 4. The strength reduction of oil-impregnated concrete is explained by the ability of oil to penetrate readily into the smallest pores and cracks, and by forcing them open, which reduces adhesion between the open portion and the coarse aggregate.

High density concrete, such as C25, C25-B, C25-A and C70, on the other hand, the concrete compressive strength development depends to a large extent on cement hydration. On coating concrete surface or unhydrated cement grains in the concrete, the oil film cuts them off from moisture, arresting their further hydration. Therefore, accumulation of concrete strength is slowed, or curtailed altogether. The extent of the effect of oil on the concrete, in this case, is characteristic of an oilsaturated concrete at an early age.

\section{CONCLUSIONS}

The effect of mineral oil on compressive strength of concrete was investigated in field and in laboratory. Five type of concrete were prepared and soaked in used mineral oil after curing period for six months. To assess the effect of used oil, tests were conducted on oiled concrete and oil-free concrete cubes at the same age. The following conclusions are made:-

1. Evaluation of the aggressive effect of mineral oil on concrete by comparing the strength on oil-free concrete and oiled concrete at the same age experimentally is the optimal and most reliable of the existing method.

2. Mineral oil is nonaggressive with respect to dense mature concrete based on the 28-day compressive strength. However its aggressiveness is very clear on compressive strength when compared with that of oil-free concrete at the same age. Presence of oil on concrete surface prevents strength gain of concrete. 
3. Mineral oil has aggressive effect on low density concrete based on the 28-day compressive strength or the compressive strength at the same age.

4. Field study showed that degree of oil contamination in concrete plays an important role in compressive strength, therefore the effect of oil soaked period needs to be experimentally investigated.

5. Presence of mineral oil in concrete increases its compressibility and in turn decreases moduli of elasticity of concrete.

6. Protection to mineral oil can be achieved by coating surfaces of R.C structures with three layers of bitumen.

\section{REFERENCES}

[1] Błaszczynski, T.; Kozarzewski, J.; Nowakowski, B. Wpływ zaolejenia na beton fundamentów pod maszyny [Effect of oil on the concrete foundations under machinery]," In:ynieria I Budownictwo [Engineering and Construction] 5-6: 1985: pp. 196-199

[2] Pluta, J.; Cias, A.; Skorupski, W. Korozja olejowa betonu konstrukcji stropów w agazynach produktów naftowych [Oil caused corrosion of concrete structures'ceiling in storage of petroleum products]. Proc. of XXVI konferencja KILiW PAN i KN PZITB, Krynica, 1980: pp. 197-203

[3] S.P. Ejeh and O.A.U. Uche. Effect of crude oil spill on compressive strength of concrete materials. Journal of Applied Sciences Research, 5(10), 2009: pp. 17561761.

[4] Runkiewicz L., Konieczny K., Brzęk R. Zmiany wytrzymałości i odkształcalności betonu zaolejonego w konstrukcji. Przegląd Budowlany, 2, 2002: pp. 26-29.

[5] Blaszczynski T. RC structures in crude oil products environment. Foundation of Civil and Environmental Engineering, No. 2, 2002: pp 2-14

[6] Mindess S, Young J. Concrete. Englewood Cliffs. New Jersey: Prentice-Hall, Inc 1981.

[7] Hamad, Bilal S., Rteil, Ahmad A. and El-Fadel, Mutassem. Effect of used engine oil on properties of fresh and hardened concrete. Construction and Building Materials, 17, (5), 2003: pp. 311-318. (doi:10.1016/S0950-0618(03)00002-3)

[8] Ayininuola, G.M. Influence of diesel oil and bitumen on compressive strength of concrete. Journal of Civil Engineering IEB, 37(1), 2009: pp. 65 - 71.

[9] Ajagbe WO et al. Effect of Crude Oil Impacted Sand on compressive strength of concrete. Constr. Build Mate., 2011. (doi:10.1016/j.conbuildmat.2011.06.028)

[10] Błaszczyński Z.T. The influence of crude oil product on RC structure destruction. Journal of Civil Engineering and Management 2011; 17(1):pp. 146156.

[11] Pukhov, I.E. Effect of mineral oil on the reinforced-concrete floors of the uglich and rybinsk hydoelecric power plants. Hydrotechnical construction, Vol. 35, No. 7, 2001: pp.370-372.

[12] Biczok, J. Concrete corrosion-concrete protection. $8^{\text {th }}$ ed. Budapest: Academiai kiado. 1972: 545p.

[13] Grabiec, K. Wpływ olejów mineralnych na wytrzymałosc i odkształcalnosc betonów konstrukcyjnych [Effect of mineral oil on the strength and deformability of concrete]. AIL 19(3): 1973: pp. 567-572. 
[14] Dominas, S. Wstepne badania cech wytrzymałosciowych betonu w srodowisku oleju mineralnego [Preliminary investigations of the characteristics of strength of concrete in the environment of mineral oil], Prace Naukowe Instytutu Budownictwa Politechniki Wrocławskiej [Scientific paper of the institute of Civil Engineering of Wroclaw University of Technology], 3. 1970.Wroclaw.

[15] Phillips, H. P.; Riewe, A. A.; Polivka, M.; Mehta, P. K. A study of the influence of oil saturation on the 64 meter antenna hydrostatic bearing grout. The Deep Space Network DSN Reoprt 42-54, 1979:pp. 62-70. (http://ntrs.nasa.gov/index.jsp?method=order\&oaiID=19800005902)

[16] Egyptian Code of Practice 203, "Basics of Design and regulations of Construction of Reinforced Concrete Structures: Appendix III, Guide for Testing of Concrete Materials," Egyptian Ministry of Housing, Egypt, 2003

[17] ASTM C42/C42M-99. Standard Test Method for Obtaining and Testing Drilled Cores and Sawed Beams of Concrete. American Society for Testing and Materials, West Conshohocken, Pennsylvania, 1999.

\section{تآثير الزيوت المعدنية علي المنشآت الخرسانية المسلحة الجزء الأول: تدهور قوة الضغط}

تقدم هذة الدراسة الجزء الأول من دراسة عامة لتآثير الزيوت المعدنية علي المنشآت الخرسانية المسلحة

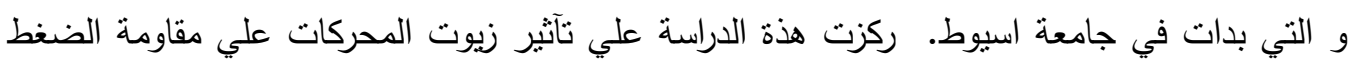

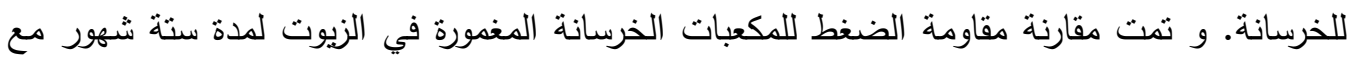
مقاومة المكعبات الخرسانية الخالية من الزيوت. و لدراسة سلوك الخرسانة نم استخدام خمسة خلطات

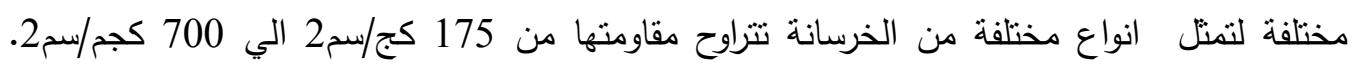
وعلاوة علي ذلك يقدم هذا البحث دراسة حقلية لتآثير الزيوت المعدنيةالمتشبعة بها الهياكل الخرسانية

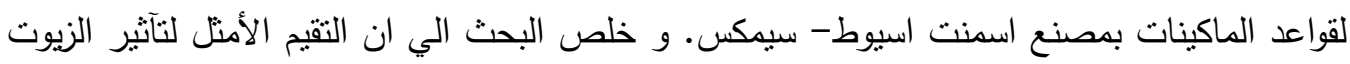

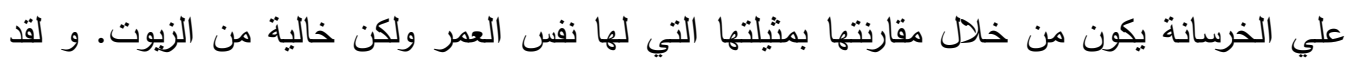

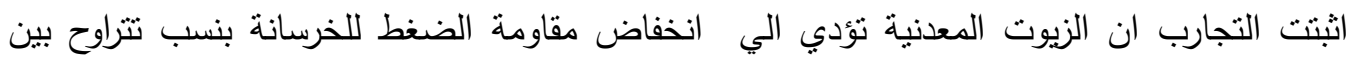

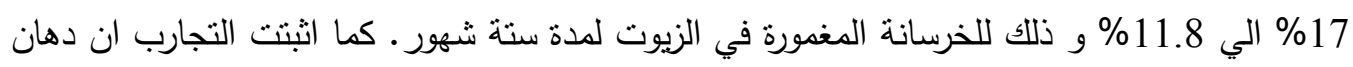

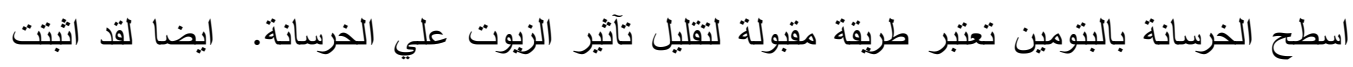

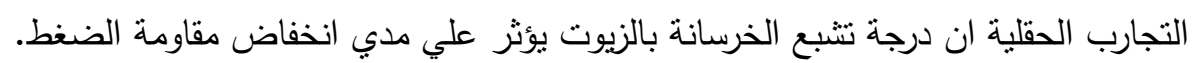

